\title{
ZBIGNIEW ŻAKIEWICZ. W CZASIE ZATRZYMANE. TOM II: ZE ZBIGNIEWEM ŻAKIEWICZEM - NA KRESACH I W BEZKRESIE, POD REDAKCJĄ KATARZYNY WOJAN (GDAŃSK, WYDAWNICTWO UNIWERSYTETU GDAŃSKIEGO, 2017, SS. 205)
}

Tom drugi wraz z częścią pierwszą o tym samym tytule $W$ czasie zatrzymane ${ }^{1}$, tworzy dwutomową księgę pamięci w hołdzie „śp. Zbigniewowi Żakiewiczowi - Literatowi, Uczonemu, charyzmatycznemu Nauczycielowi wielu pokoleń znakomitych akademików”. W dziękczynnej, ogromnie uważnej i dyskursywnie precyzyjnej Przedmowie redaktor obydwu tomów Katarzyna Wojan podkreśla gatunkowo heterogeniczne treści tomu komentarzowego, tak adekwatne do przebogatej kulturowo sylwetki bohatera wydania i jego dorobku.

Moja opinia na temat tomu to tylko kilka refleksji literaturoznawczych na stronie.

Tytuł dwutomowego wydania jest cytatem, zaczerpniętym z tytułu dzieła samego Autora: Zbigniew Żakiewicz, Ujrzane, w czasie zatrzymane, Biblioteka „Tytułu”, Gdańsk: Marabut 1996, i może sugerować dyskursywną metaforę 'pisania Żakiewiczem', co wydaje się również bardzo adekwatne dla wielu tekstów tomu. Także podtytuł drugiego tomu: Ze Zbigniewem Żakiewiczem na Kresach i w bezkresie, znakomicie projektuje jego zawartość, składającego się z czternastu artykułów, z których część konceptualizuje właśnie geograficzno-spacjalny, przestrzenny plan tekstów Żakiewicza, by dociec w ten sposób fenomenu jego kulturowej tożsamości.

Jako repatriant z Kresów Wschodnich do Polski centralnej, zamieszkały następnie już do końca życia w granicznej nadmorskiej przestrzeni - w Gdańsku, Zbigniew Żakiewicz poszukiwał tożsamości w kontekście wielokulturowości, w „skazie” azjatyckością, związaną, z jednej strony z jego tatarskim rodowodem, z drugiej - interpretowaną przez rosyjską literaturę jako turkijski (azjatycki) element rosyjskiej mentalności, który przesądził o jej, Rosji, historiozoficznym manicheizmie.

1 Zbigniew Żakiewicz, W czasie zatrzymane, t. I: Wybór szkiców literackich z lat 1977-2008, zebrał M. Żakiewicz, oprac. naukowo oraz wstępem opatrzyła K. Wojan, Gdańsk 2017: Wydawnictwo Uniwersytetu Gdańskiego. 
Poszukiwanie przez Żakiewicza własnej tożsamości staje się dominantą problemową materiałów zawartych w obydwu tomach, a w tomie komentarzowo-badawczym zorientowaną na semiotykę granicy oraz lustra, odbicia, enancjomorfizmu (semiotyki lustrzanej).

Franciszek Apanowicz w tekście Moje spotkania ze Zbigniewem Żakiewiczem Pisarzem, Nauczycielem, Człowiekiem konstatuje, że „problem nieuchwytnej, rozszczepiającej się tożsamości stanowi jeden z ważniejszych motywów”, cytując fragment Wilczych Łąk:

Jest tak, jakbym przed lustrem stał, w sobie był skryty, przez siebie odczuwany i przez tego drugiego siebie w lustrze oglądany. A gdy jeszcze lustro do tego lustra się przystawi, wówczas otwierają się stopnie lustrzane w głąb wiodące. Stopień po stopniu - a w każdym razie ja jestem wtopiony jak mucha w żelatynę. I tak zstępuję w głębię. Tu jestem taki, jaki jestem teraz, a tam - uciekający w przestrzeń bez granic i sam jestem w tym lustrze bez granic. I czasu dla mnie nie ma... (cyt. za Apanowiczem, s. 80).

Tekstocentryczny charakter osobowości bohatera tomu strukturuje nie tylko pograniczność jako najwłaściwszą dla samoświadomości perspektywę, jak też uważał Michaił Bachtin, ale i utrwaloną przez romantyków i trwale przypisaną Rosji „bezgraniczną pustkę”, „bezkres” właśnie - jako kategorię kulturową. W ten sposób pojęcie „bezkresu” w podtytule książki uzyskuje tropeiczną dwuznaczność: kosmiczne konotacje „bezkresu” jako wieczności/universum/wszechświata - z jednej strony, z drugiej - przestrzenną oraz mentalną charakterystykę Rosji. Obydwa sensy odpowiadają już nieziemskiemu statusowi Żakiewicza-człowieka oraz komunikatywnie inspirującej nieskończoności-niewyczerpywalności jego tekstów jako pisarza i naukowca.

Tytułowy „bezkres” jako metafora Rosji, którą Żakiewicz, rusycysta i rosjoznawca, odnajdywał w sobie samym jako pierwiastek manichejski, wschodni, azjatycki, krzyżuje się z jego doświadczeniem przestrzeni geograficznej. W artykule Miłosza i Żakiewicza manichejski klucz do Rosji Zbigniew Kaźmierczyk przekłada kod geograficzno-spacjalny na filozoficzno-egzystencjalny, tak bliski Żakiewiczowi, czytającemu „Rosję azjatycką":

Persewerującym motywem pisarza stanie się bezkres: „Kraina pusta, ziemia wyzyskana i opuszczona" (...). Minie trzydzieści lat, aż refleksja na temat przestrzeni powiąże się z manichejskim egzystencjalizmem.

Analiza komunizmu uwzględni tym razem profecję Włodzimierza Sołowjowa, który głosił nadejście panowania panmongolizmu nad Europą. U Aleksandra Błoka tą niszczycielską siłą jest rosyjski lud. Żakiewicz w Buninie widzi gorliwego piewcę zniszczenia przez ten lud starego świata. Piewcy oczyszczenia przez krew interesują polskiego pisarza jako antyświatowi dualiści, którzy bezmierną tęsknotę (jak bezkresną przestrzeń Rosji) łączyli z akcją rewolucyjną pod hasłem: „wszystko albo nic” (...) (s. 53).

Uwikłanie w kulturowe i geograficzne transgresje, widzenie z pozycji pogranicza, z miedzy semiotycznej, którą to perspektywę Bachtin uważał za najbardziej produktywną dla rozumiejącego oglądu cudzego vs. swojego, to, podobnie jak u Czesława Miłosza, znak firmowy pisarstwa Żakiewicza. Jak przekonuje Kaźmierczyk:

Rosja Dostojewskiego stała się dla Żakiewicza sposobnością wglądu w samego siebie i poprzez siebie odkrywanie Rosji (s. 49). 
Kategorie przestrzeni i tożsamości sprzęgają się w twórczości Żakiewicza, kreując jego indywidualną poetykę. Bardzo udanie eksplikuje ją Bogusław Żyłko w mitopoetologicznym studium Wyobraźnia przestrzenna Zbigniewa Żakiewicza, poświęconym kartograficznej poetyce Żakiewicza. W perspektywie semiotyczno-filozoficznej Żyłko analizuje takie lokusy w Żakiewiczowskiej twórczości literackiej i paraliterackiej (dzienniki, szkice, felietony, przygodne zapiski), które mają wymiar archetypalny oraz chronotypalny, czasoprzestrzenny, jak Kosmos i Dom. Bardzo niebanalnie, bo w konwencjach Gogola, odczytuje też przestrzenne modelowanie Krajobrazów jako grę deformującymi przestrzeń i mapę artystyczną punktami widzenia.

Żakiewiczowską poetykę tożsamości intrygująco analizuje Kazimierz Nowosielski, łącząc dociekania nad mechanizmem narracji, prowadzonej przez nieoczywistego dla czytelnika narratora N.N. - autorskiego sobowtóra, współgrającego z realnym zachowaniem Autora-człowieka:

Można domniemać, iż właśnie na użytek zamieszczonych w obu utworach (Dziennik intymny mego N.N. oraz Pożądanie Wzgórz Wiekuistych - A. M.) tożsamościowych dywagacji, obserwacji i przemyśleń pisarz stworzył tytułowego N.N. - kogoś jakby identycznego z nim i nieco obcego mu jednocześnie (...) - kogoś niby nieznanego samemu twórcy (wszak skrótem nn zwykło się oznaczać człowieka $\mathrm{z}$ istotnych powodów ważnego, acz anonimowego; łac. nomem nescio; co się wykłada: imienia nie znam), choć przecie przez niego samego powołanego do literackiego zaistnienia. Raz zdaje się on jakimś superego artysty (jego nadjaźnią), raz - tym, co najdogłębniej skryte i niedostępne w nim samym (id), czasem aniołem stróżem, doradcą, powiernikiem lub adwersarzem nawet. Bywa, że prezentuje się jako jego zwierciadlane odbicie, cień, sobowtór... W każdym razie widzimy w nim swoistego świadka i uczestnika owego niezwykle istotnego dla całości pisarskiego dorobku autora Rodu Abaczów sporu o sens i wartość (antropologiczną, metafizyczną, estetyczną...) zagadnień związanych z ludzką tożsamością. Jego obecność także da się odnaleźć nawet w najbardziej fikcjonalnych utworach gdańskiego prozaika (s. 68-69).

Zaświadczając wielostronność i głębię Żakiewicza jako pisarza gdańskiego, omawiany tom stanowi wydarzenie literaturoznawcze o ponadregionalnym wymiarze. Harmonijnie i wzorcowo łączy on bowiem czuły dyskurs eseistyczno-wspomnieniowy $\mathrm{z}$ terminologiczno-kategorialną dyscypliną badawczą $\mathrm{w}$ jej nowoczesnym wydaniu: $\mathrm{z}$ poetyką, tak adekwatną do literaturocentryzmu bohatera tomu, że swojej opinii o tomie nie bałabym się zaliczyć do kategorii prac na temat „literatury w teorii”, że posłużę się formułą tytułu monografii amerykańskiego literaturoznawcy Jonathana Cullera (2013, s. 29).

Już sama kompozycyjna dwuczęściowość niniejszej edycji programuje dyskurs literaturoznawczy jako strukturalną dominantę tomu drugiego, badawczo-komentarzowego wobec paraliterackiej twórczości Żakiewicza, zaprezentowanej $\mathrm{w}$ tomie pierwszym. Warto więc $\mathrm{w}$ tym miejscu przypomnieć, że właśnie dyskurs literaturoznawczy jest dzisiaj kluczowy w perspektywie interdyscyplinarnej, literatura bowiem jest dziś „własnością różnorodnych dyskursów, których literackość - własności narracyjne, retoryczne i performatywne - można analizować przy pomocy metod zarezerwowanych dotąd dla analizy literackiej” (Culler, 2013, s. 29). Tak dla przykładu historyczne badania Nowego Historycyzmu obierają za swój przedmiot nie tyle historyczne wyjaśnianie, ile objaśnianie struktur zainteresowania literackiego. 
Także „akademią rządzi literatura, choć rządzi w przebraniu. (...) szereg naukowców i dyscyplin stosuje do opisu świata terminy wywiedzione z terenu badań literackich. Bada także różne wymiary tego zjawiska: powrót praktyki opowiadania do kręgu podstawowych zagadnień w historii (mówi o „epidemii opowiadania”), która miała się za wolną od takich humanistycznych, literackich zatrudnień, powszechny powrót do anegdoty i autobiografii, pochwała „gęstego opisu” i „wiedzy lokalnej”, a także wykorzystywanie figury „rozmowy” w historii, filozofii, feminizmie czy antropologii. Dzisiejsza przemiana nauk humanistycznych polega na tym, że wiedza przyjmuje formy literackie. (...) Literatura rządzi", twierdzi Culler (2013, s. 29), a niniejszy tom to potwierdza.

Literaturoznawczy dyskurs omawianego tomu wybija się na plan pierwszy już w Przedmowie Katarzyny Wojan, podkreślającej ujęcie twórczości Żakiewicza poprzez pryzmat poetyki (dodajmy: jako teorii dzieła literackiego): „Na niniejszy tom składa się czternaście artykułów dotyczących wybranych wątków biograficznych oraz refleksji na temat twórczości literackiej i naukowej Zbigniewa Żakiewicza (1933-2010), tworzących jego unikalny portret pisarski”. Jako zdanie wprowadzające w zawartość tomu łączy twórczość pisarską i naukową poprzez słowo „refleksja”, przywołując kontekst teorii z jej analitycznością i refleksyjnością. Istotnie, mówiąc o tekstach omawianego tomu, Autorka Przedmowy różnicuje ich charakter jako struktur wypowiedzeniowych, akcentując w ten sposób komunikacyjny aspekt tekstowej zawartości tomu, co podobnie jak samo operowanie pojęciem „tekstu” jest wyznacznikiem dyskursu o semiotycznej proweniencji.

Tom drugi jako całość istotnie przynosi instruktywny wgląd w dzieło życia Zbigniewa Żakiewicza poprzez jego poetyki, badawcze praktyki struktur tekstowych, zarówno artystycznych, jak i paraartystycznych oraz naukowych. Klucz poetologiczny okazuje się najadekwatniej dobranym kluczem, bowiem rozpiętość geograficzno-kulturowa dzieła Pisarza i Badacza, jak i Jego złożony rodowód etniczny implikują wielość poetyk: etniczną, kartograficzną itd.

Tatiana Czerska jako głęboka znawczyni pisarstwa Żakiewicza także akcentuje tę wielość poetyk, m.in. poetykę groteski i literatury sobowtórowej, mitu, konfesyjną, poetycką. Poetologia zaś, czyli badanie poetyki „polega właśnie na owej próbie rozwijania systematycznego rozumienia semiotycznych mechanizmów literatury - przeróżnych strategii jej form" (Culler, 2013, s. 220).

Anna Majmieskułow, Bydgoszcz, 25.09.2018

\section{Bibliografia}

Culler, J. (2013). Literatura w teorii. Przeł. M. Maryl. Kraków: Universitas.

Żakiewicz, Z. (2017). W czasie zatrzymane. T. 1: Wybór szkiców literackich z lat 1977-2008. Zebrał M. Żakiewicz. Oprac. naukowo oraz wstępem opatrzyła K. Wojan. Gdańsk 2017: Wydawnictwo Uniwersytetu Gdańskiego.

ANNA MAJMIESKUŁOW

Emerytowany prof. nadzw. Uniwersytetu Kazimierza Wielkiego w Bydgoszczy e-mail: majmiesk@ukw.edu.pl 